\title{
Domestic Politics and US-China Trade Disputes over Renewable Energy
}

\author{
Ka Zeng
}

\begin{abstract}
In this article I draw on the two-level game approach to analyze the influence of domestic politics on US-China trade disputes in alternative energy, especially in solar energy. I suggest that the difficulty Washington faces in getting China to address market access barriers in alternative energy needs to be viewed in light of both the coalitional dynamics in the United States resulting from the specific bilateral trade and investment relationship in this sector and Beijing's willingness to use industrial policy to foster economic competitiveness in nascent industries. Specifically, as China occupies the middle of the supply chain in the solar industry, both downstream users of low-cost Chinese imports and exporters of upstream products to China have voiced strong concerns about US trade action. Such domestic opposition, coupled with the importance of industrial policy for defending the country's long-term interests in a "strategic emerging" sector such as alternative energy, substantially constrains Washington's ability to influence Chinese policies. Keywords: United States, China, trade disputes, renewable energy, solar energy, TRIMs, domestic politics, two-level games
\end{abstract}

IN THIS ARTICLE I DRAW ON THE TWO-LEVEL GAME APPROACH TO ANALYZE the influence of domestic politics on US-China trade disputes in alternative energy, especially in solar energy. I suggest that the difficulty Washington faces in getting China to address market access barriers in alternative energy needs to be viewed in light of both the coalitional dynamics in the United States resulting from the specific bilateral trade and investment relationship in this sector and Beijing's willingness to use industrial policy to foster economic competitiveness in nascent industries. Specifically, as China occupies the middle of the supply chain in the solar industry, both downstream users of low-cost Chinese imports and exporters of upstream products to China have voiced strong concerns about US trade action. Such domestic opposition, coupled with the importance of industrial policy for defending the country's long-term interests in a "strategic emerging" sector such as alternative energy, substantially constrains Washington's ability to influence Chinese policies. 
China's rapid export growth in recent years has generated heightened tensions in its trade relations with the United States, leading both to more industry-initiated trade cases and more frequent resort to the dispute settlement mechanism (DSM) of the World Trade Organization (WTO) to address its market access concerns. This article examines Washington's efforts to address Beijing's compliance with its commitments to the Agreement on Trade-Related Investment Measures (TRIMs) in alternative energy, especially in solar energy. I argue that while the US government and industry have evinced no less intense concerns with Chinese practices in solar energy than in other TRIMs-related sectors such as wind power, it has achieved the least success in eliciting positive Chinese response in this sector.

I further draw on the two-level game approach to develop a framework for understanding the above pattern, suggesting that the degree to which the relevant actors in the United States are united in support of an aggressive market opening strategy and the degree to which the Chinese leadership and other relevant actors are strongly in favor of defending the alleged market access barriers play an important role in explaining the case outcome. Washington's effort to open the Chinese market is least likely to generate the desired outcome when domestic business groups in the United States are divided over the trade policy and when the Chinese leadership has demonstrated intense resolve in defending the problematic policies, especially in sectors in which the scale of existing policy commitment has rendered policy changes difficult.

Applying the above framework to US-China trade disputes in solar energy, I suggest that the difficulty faced by the United States in getting China to modify its practices in the solar industry needs to be viewed in light of both the coalitional dynamics in the United States resulting from the unique nature of the bilateral trade and investment relationship in this sector and Beijing's willingness to use industrial policy to foster economic competitiveness in nascent industries. Specifically, as China occupies the middle of the supply chain in the solar industry, both downstream users who rely on low-cost Chinese imports and businesses that export upstream products to the Chinese market have voiced strong concerns about US efforts to impose trade restrictions against China. Furthermore, growing Chinese investment in the US solar industry has led US subsidiaries of Chinese solar companies to join the debate in opposition against the trade restrictions. Such domestic resistance, reinforced by the importance of industrial policy for defending the country's longterm interests in a "strategic emerging" sector, especially one in which prior government investment has generated substantial current "sunk costs," has substantially constrained Washington's ability to influence 
Chinese policies. While the US industry has mainly chosen to express its trade concerns through administered forms of trade protection such as antidumping (AD) and countervailing duties (CVD) in the solar case, it is inappropriate to view these measures as purely neutral administrative processes because Congress writes the rules about them in a way that reflects its policy interests. My research findings therefore hold, regardless of the venue of dispute initiation chosen by US industry.

\section{Insights from the Two-Level Game Approach}

I draw on the two-level game literature to analyze the influence of domestic politics on US-China trade disputes in alternative energy, especially in solar energy. The two-level game literature emphasizes the importance of domestic politics for international bargaining strategies (e.g., Evans, Jacobson, and Putnam 1993; Odell 1993). A country's market opening strategy will be more successful if the relevant domestic actors are united in support of such a strategy. Conversely, foreign threats of trade retaliation will be less effective if domestic interest groups in the target country are uniformly opposed to market liberalization or if there exists strong pressure against policy changes in the target country.

In considering the intensity of pressure against the status quo in the specific target country that is the focus of this study, China, I adopt a rationalist, leader-oriented cost-benefit framework that emphasizes both the tangible and intangible economic and political interests underlying the calculations of top elites that influence China's foreign economic policy (see Keohane 1988; Harsanyi 1969; Hasenclever, Mayer, and Rittberger 2000; Martin and Simmons 1998; Hudson and Vore 1995). In analyzing the policy preferences of domestic actors toward international cooperation, the leader cost-benefit framework utilized in this study stresses how, in spite of the proliferation of societal interests and their growing ability to influence the decisionmaking process in an authoritarian regime such as China, top elites are nevertheless uniquely positioned to defend the country's economic interests, including industrial policies (see Blanchard and Ripsman 2008). As top elites in China seek to enhance the country's economic and technological competitiveness, promote further market liberalization, and boost long-term economic growth potential (e.g., Blanchard 2013; Wang 2005; Shih 2004), it is reasonable to expect that they will continue to use the instruments at their disposal to influence China's foreign economic relations in ways that enhance the country's wealth and power as well as influence in global economic governance. 
The above insights should lead us to expect Washington's efforts to influence Chinese policy to be most effective when they enjoy the support of key domestic groups in the United States and when the Chinese leadership and other relevant domestic actors have weak commitment to the alleged trade barriers (upper right cell in Table 1). Conversely, US trade initiatives should induce the least concessions when domestic actors in the United States are divided over the negotiation strategy and when the relevant domestic actors in China are strongly united in defense of the alleged trade barriers (lower left cells). Cases combining a high level of domestic unity in the United States and a high level of unified domestic support for the problematic trade policies in China (upper left cell) or a low level of domestic unity in the United States and a relative lack of Chinese interest in protecting the sector in question (lower right cell) should yield intermediate outcomes. The US-China trade disputes over solar energy should fall into the lower left cell both because of the substantial division among domestic interest groups in the United States arising from the unique market structure in this sector and the difficulty the Chinese government at both the central and local levels faces in making policy adjustments in "strategic emerging" industries, particularly one in which it has made a substantial commitment such as solar.

Before proceeding, a few caveats are in order. First, in considering the Chinese leadership's resolve in defending the industry under consideration, I examine both the degree to which an industry is considered to be a strategic industry of vital importance to the country's long-term economic well-being and the degree to which the government has incurred substantial "sunk costs" in the form of prior investment and other policy commitments. This is because even though two industries are of equal

Table 1 Hypothesized Effect of Domestic Politics on the Effectiveness of Market Opening Pressure

\begin{tabular}{l|c|c|c}
\hline \multicolumn{2}{l|}{} & \multicolumn{2}{|c}{ Level of Commitment to the Alleged Trade Barriers in China } \\
\cline { 3 - 4 } \multicolumn{2}{l|}{} & High & Low \\
\hline \multirow{2}{*}{$\begin{array}{l}\text { Domestic Unity } \\
\text { in the United States }\end{array}$} & High & Intermediate outcomes & Most concessions \\
\cline { 2 - 4 } & Low & Least concessions & Intermediate outcomes \\
\hline
\end{tabular}


strategic importance, it is reasonable to expect that the leadership would be less likely to make the necessary policy concessions in a sector where the scale of existing commitment would have substantially increased the costs of a major policy reversal. Thus the Chinese government made fewer concessions in solar than in wind power because of the substantial support that the government at both the central and local levels has provided to the solar industry during the period under consideration. While the wind industry has received substantial government support in the past, such distant sunk costs seem less salient to policymakers than current sunk costs such as those associated with the solar industry.

Second, in terms of the indicators of the political situations in the two countries that I use in the analysis, the above argument calls for an in-depth analysis of the preferences and lobbying activities of the main affected interest groups in the United States. While Chinese politics is less transparent, the rationalist, leader cost-benefit framework outlined above calls for a detailed and careful examination of the priority the government attaches to the industry as reflected both in the government's policy pronouncements and documents and in the actual evolution of its industrial policy in the sector(s) under consideration. Given the key role of the central government in shaping China's industrial policy, the analysis will necessarily devote the most attention to the preferences of the central government. But in view of the growing ability of subnational actors and sectoral interests to influence China's economic policy, it will also take into account the role of local government and industry associations in influencing the case outcome.

Third, in measuring the extent of Chinese resistance to US trade pressure, I emphasize not only the degree to which the Chinese government has undertaken retaliatory measures in response to US trade restrictions but also the amount of time it took for China to address US concerns as well as the degree to which the Chinese leadership has made concrete policy changes in response to US pressure. Thus the Chinese leadership would be considered to be most resistant to market opening moves in the solar case both because Beijing has responded to US tariff restrictions by initiating its own investigations and WTO complaint and because the issue has frequently resurfaced in US-China trade relations and remains an active concern of the US government and industry. While the United States successfully imposed trade restrictions on Chinese imports, this does not necessarily mean that it has succeeded in altering the basic market fundamentals. Furthermore, even though the Chinese government has made some concessions to the United States in the solar case because it eventually shifted focus from solar exports to emphasize domestic con- 
sumption, that shift came mainly as a result of the bankruptcies and financial difficulties faced by domestic firms instead of tensions in the bilateral trade relationship. US trade pressure played at best a secondary role in the observed policy changes. ${ }^{1}$

Fourth, it should be pointed out that domestic industries in the United States have multiple channels through which to influence Chinese policy. In addition to filing a petition under Section 301 of the 1974 Trade Act that may eventually result in WTO litigation, an industry also has the option of pursuing administered trade protection based on the Tariff Act of 1930 by filing antidumping or countervailing duty investigations with the Department of Commerce. And these two processes are not mutually exclusive. It is important to note that I do not focus solely on $\mathrm{AD} / \mathrm{CVD}$ investigations, nor is my main argument necessarily premised on the dispute's going through one dispute settlement channel or another. While AD/CVD investigations typically involve an automatic investigative process on the US side that is apolitical and does not involve any bilateral negotiations, the repeated emergence of an issue (such as Chinese subsidies in the solar case) nevertheless provides an indication of persistent US concerns in a given issue area. The extensive coverage the solar case has received in the media effectively sent a signal to the Chinese that they would face additional punitive tariffs unless measures are taken to address the alleged market barriers. By increasing the economic costs Chinese leaders face for refusing to make the necessary policy adjustments and raising the specter of WTO litigation on this issue, the frequent resort to $\mathrm{AD} / \mathrm{CVD}$ investigations may therefore implicitly affect the costs for the Chinese to continue to hold onto the status quo. Indeed, addressing excess capacity in the solar industry is increasingly at the forefront of the agenda of the US-China negotiations such as those carried out under the framework of the Joint Commission on Commerce and Trade (JCCT). ${ }^{2}$ The solar disputes thus have the potential to affect the overall trajectory of US-China bilateral economic cooperation as well as the political environment in which Chinese decisionmakers operate. Additionally, while the solar trade case can be judged as a success in that the main petitioner in this case, Solar World, received the tariffs it was seeking, the long-term market impact of the tariffs remains questionable due in large part to the political dynamics outlined in this article.

Finally, in examining the extent of China's policy adjustments, I focus on those policies that are either prohibited by or potentially actionable under the WTO. While there is yet no unified consensus in the trade policy community as to how to distinguish infant industry policies that are not necessarily distortionary from those policies that simply provide 
an unfair advantage to domestic producers, the WTO does have rules for disciplining the use of trade-distorting measures. With respect to subsidies that are most frequently used in the renewable energy sector, the WTO's Agreement on Subsidies and Countervailing Measures (SCM) specifically prohibits subsidies that are designed to distort international trade, such as those that require recipients to meet certain export targets or to use domestic instead of imported goods. The SCM additionally allows the complaining country to impose countervailing duties on certain actionable subsidies if it can show that the subsidy has an adverse effect on its interests. ${ }^{3}$ While the United States has challenged China's prohibited subsidies, such as export or local content subsidies at the WTO, it has also sought to address actionable subsidies such as the provision of discounted land and electricity, low-interest loans, and tax reduction through its domestic legal remedies (Hong and Huang 2014; Chen and Tu 2013). Consequently both types of subsidies and related remedies will receive some attention in the following analysis.

\section{China's Rapid Ascent in the Global Solar Industry}

China's rapid ascent in the global solar industry provides the broad backdrop for understanding rising US-China trade tensions in this sector. Chinese manufacturers entered the global solar equipment market in 2004 when demand for such products experienced significant increases worldwide, in particular in Europe. Government support, along with the country's low labor costs; massive supply chains; lax labor, safety, health, and environmental standards, played an important role in propelling the rapid expansion of China's solar production (Hart 2012). In particular, as the Chinese government targeted the solar panel manufacturing industry as part of its stimulus plan in the aftermath of the 2008 global financial crisis, private investment followed. Major Chinese solar companies such as Suntech, LDK Solar, and Yingli Solar all quickly entered the market and borrowed extensively. Growing global corporate and household demand for solar photovoltaic (PV) panels resulting from both environmental concerns and generous government subsidies in the European Union and the United States further fueled the growth in renewable energy production in China.

As a result of the confluence of market supply and demand conditions and the ability of Chinese enterprises to price products competitively, China had become the leading producer of solar cells in the world by 2007 and the largest producer of solar panels by 2008. Figure 1, which presents China's rapid ascendance to dominance in the global solar PV 
Figure 1 China's Swift Ascendance to Global Solar Photovoltaics Market Dominance, 2000-2012

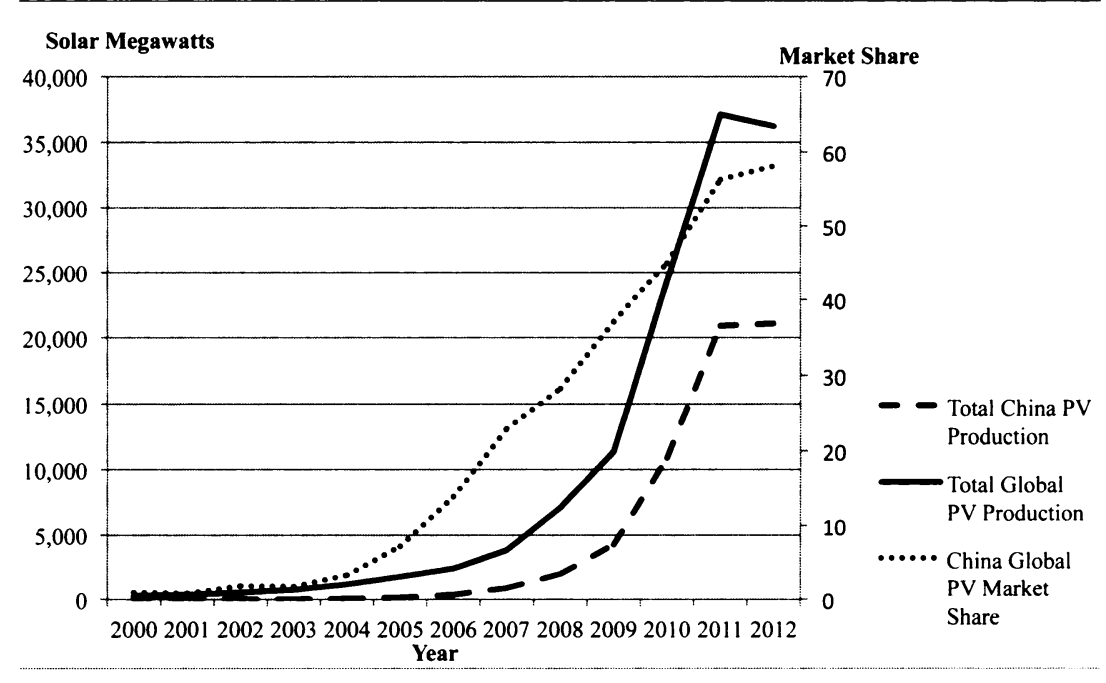

Source: Earth Policy Institute

market, shows that the country has been able to increase its share of the global market from just 15 percent in 2006 to almost half by 2010 (Hart 2012). Its solar module manufacturing capacity further grew from less than 5 gigawatts (GW) in 2007 to about $40 \mathrm{GW}$ in 2011, more than double the total manufacturing capacity in the rest of the world (Parker 2012).

However, the rapid expansion of China's solar manufacturing capacity quickly outpaced both domestic and global demand for solar module installations. Total global demand for solar module installations was only less than $5 \mathrm{GW}$ in 2007 , rising to about $30 \mathrm{GW}$ by 2012 , with the rest of the world accounting for most of this increase. China's solar module supply glut resulting from overinvestment thus directly threatened the viability of solar companies elsewhere in the world, leading US companies such as Solyndra and Evergreen Solar to declare bankruptcy (Parker 2012). China's swift ascendance to dominance in the global solar PV market and the competitive pressure it exerted on solar manufacturers in the United States thus set the stage for the US trade challenges against China. 


\section{Rising US-China Tensions in Renewable Energy}

China's emergence as a major player in the global clean energy industry has captured considerable external attention in recent years. In December 2010, the United States requested WTO consultations (DS 419) with China on the grounds that certain Chinese measures providing grants, funds, or rewards to enterprises manufacturing wind power equipment were "contingent on the use of domestic over imported goods" and therefore violated Chinese commitments to the Agreement on Subsidies and Countervailing Measures (SCM agreement). ${ }^{4}$ WTO consultations led China to quickly agree to take actions to revoke the legal measure that created the Special Fund Program in July 2011(USTR 2011). ${ }^{5}$

However, China's relatively swift concessions in the wind power case by no means signaled the end of bilateral tensions in the green tech sector. In March 2012, following four months of investigations, the Commerce Department imposed countervailing duties on Chinese manufacturers of solar cells on the grounds that they had continued to receive subsidies from the Chinese government. Four months later, the United States moved to impose antidumping measures on Chinese solar panels in a separate investigation (Politi and Lerner 2012). US tariffs in turn led Beijing to respond by launching its own investigations into six cleanenergy products in five US states that had allegedly received illegal support from the US government, in addition to filing a WTO complaint against US countervailing duties on a range of Chinese products, including solar panels (Mufson 2012). In December 2013, one of the key proponents of punitive tariffs against China, SolarWorld, filed another antidumping and countervailing duty petition aimed at imports of solar products from China. In December 2014 the Commerce Department issued the final ruling that Chinese manufacturers had unfairly benefited from government subsidies and imposed antidumping duties ranging from 26.71 percent to 78.42 percent on most solar panels imported from China and antisubsidy duties of 27.64 percent to 49.79 percent on Chinese modules (Cardwell 2014).

It should be noted that US solar manufacturers have chosen to address their trade concerns primarily through domestic legal trade remedies instead of WTO litigation. ${ }^{6}$ However,the fact that Beijing has engaged in tit-for-tat retaliation suggests that it does not necessarily view $\mathrm{AD} / \mathrm{CVD}$ actions in isolation from the broad bilateral trade relationship in this sector. It is also important to note that despite opposing efforts from both downstream and upstream producers described below, solar manufacturers succeeded in initiating the case because they were able to make a strong argument to the authorities about the importance of import 
protection in a strategically important industry such as renewable energy. It also subsequently gained positive rulings because the designation of China as a nonmarket economy in $\mathrm{AD} / \mathrm{CVD}$ investigations has lessened the burden for US industry to provide evidence of injury from Chinese competition. ${ }^{7}$

While the United States has sought to address its concerns with Chinese practices in both the solar and wind power sectors through multiple channels, it seems to have been less successful in influencing Chinese policy in solar than in wind power. To be sure, $\mathrm{AD} / \mathrm{CVD}$ investigations are rather technical processes that are targeted presumably at firm behavior. While they are not necessarily intended to influence Chinese policy, the frequent use of retaliatory measures and the resurfacing of the issue in the bilateral trade policy agenda suggest that the trade barriers and practices in the solar industry remain an ongoing and active concern to US business interests and that the Chinese government has not been very forthcoming in addressing the alleged trade barriers. ${ }^{8}$

US-China trade disputes in the wind power industry seem to be more muted by comparison. The United States did impose antidumping and countervailing duties on utility-scale wind towers from China to offset the effect of subsidies provided by the Chinese government in December 2012, but bilateral trade disputes have been far less frequent in this sector. Furthermore, as mentioned above, the policy adjustments Beijing did make in the solar sector resulted primarily from domestic considerations instead of external pressure. Overall, while the United States has exerted considerable pressure on China to end its alleged violations in solar energy through both WTO litigation and other trade policy instruments, it continues to face an uphill battle in getting Beijing to address these concerns as a relatively large number of potentially TRIMs-noncompliant policies with significant negative commercial implications for the United States remain.

\section{Explaining the Ineffectiveness of US Trade Policy over Solar Energy}

This section argues that the ineffectiveness of US trade policy in solar energy can be explained by domestic dynamics in both countries. First, the market structure in renewable energy, especially in the solar industry, has given rise to coalitional dynamics in the United States that rendered the US position less credible to the Chinese. Second, alternative energy represents a pillar or strategic industry for Beijing whereby industrial policy is viewed as a key instrument for fostering the country's indige- 
nous high-tech industries, promoting exports, and enhancing the prospect of long-term economic growth. This was further reinforced by the particularly strong support the Chinese government has provided to the solar industry in relation to other renewable energy sectors such as wind at the time of the trade disputes and consequently the far more significant costs that would be incurred if China were to scale back its policy commitment. The strategic importance of the solar industry, along with the significant sunk costs the government has incurred through prior support, therefore reduced the Chinese leadership's incentives for concessions.

\section{Market Structure and the Cohesiveness of the US Position}

The rapid growth of trade and investment relationships between China and the United States in solar energy has substantially increased the dependence of some segments of the US solar industry on Chinese products. As a result, a broad coalition consisting of downstream installers, companies that sell solar manufacturing equipment and other upstream products, and US subsidiaries of Chinese solar companies who have gained increasing foothold in the US market has emerged to counter solar manufacturers' push for punitive trade sanctions.

Importantly, US-based solar manufacturers who directly compete with Chinese imports strongly supported efforts to impose trade restrictions against China. For example, solar module manufacturers such as SolarWorld Industries America, the largest manufacturer of crystalline silicon PV cells in the United States, and Helios Solar Works alleged that the use of dumping and illegal subsidies by the Chinese government has resulted in the artificial suppression of solar panel export prices by a margin of at least 100 percent. As cheap Chinese exports played an important role in the 50 percent drop in solar panel prices in 2011 that eroded profit margins worldwide, import tariffs on Chinese products could potentially halt or even reverse this trend and increase profit margins for US manufacturers, in addition to helping to create a more level playing field in the US market (Hart and Gordon 2012). Other major US producers of solar cells and panels, represented by the Coalition for American Solar Manufacturing (CASM), further attributed industry plight-including considerable cutbacks or downsizing as well as the bankruptcies of a number of US companies - to the subsidies and other forms of support the Chinese government provided to the solar industry. ${ }^{9}$

It should be noted though that the solar value chain consists of multiple players, including both upstream players that engage in research and development, product manufacturing, and distribution as well as downstream players such as installers and companies that distribute prod- 
ucts directly to consumers. Indeed, businesses that provide supporting equipment to solar panels such as steel structures and cables and services such as installation and maintenance comprise more than half of the solar value chain ( $\mathrm{Lu} \mathrm{2012).} \mathrm{These} \mathrm{downstream} \mathrm{installers} \mathrm{have} \mathrm{therefore}$ voiced strong concerns about the costs that increased solar panel prices would inflict on their services.

For example, solar panel installers such as SunEdison, Q.Cells, and Standard Solar consistently opposed the investigation on the grounds that it would result in higher panel prices in the United States, thus lowering rates of installation and threatening up to 60,000 jobs in the United States. For example, Jigar Shah, founder of SunEdison, stated that while the US move "is a relatively positive outcome for the U.S. solar industry and its 100,000 employees, . . . tariffs large and small will hurt American jobs and prolong our world's reliance on fossil fuels." Similarly, the vice president of SunEdison stated that "by increasing the price of modules and therefore the price of solar energy, these tariffs will undermine the success of the U.S. solar industry and reduce the ability of solar energy to compete with electricity generated from fossil fuel" (O'Tooley 2012). The chief executive officer of Q.Cells further suggested that the issue was broader than panel prices and raised the challenge for the United States to "stay focused on providing reliable, predictable and sustainable energy solutions for utilities and other customers" (Carus 2012).

Concerned that import tariffs would erode their profit margins, slow industry growth across the value chain, and further increase the difficulty for solar energy to compete with traditional fossil fuels, the solar installation firms have coalesced around the Coalition for Affordable Solar Energy (CASE) to counter the claims made by solar panel manufacturers. The coalition argued that imposing high import tariffs on Chinesemade solar panels would eliminate thousands of jobs in that sector and threaten to drive the US solar installation industry, which accounted for 52 percent of all US solar industry jobs, out of existence (Bradsher and Cardwell 2012; Hart and Gordon 2012). In defending its claims, the CASE cited a research report prepared by the Brattle Group showing that a 50-100 percent tariff would lead to "net consumer losses" ranging from $\$ 621$ million to $\$ 2.6$ billion and job losses of up to 60,000 over the following three years. The likely Chinese retaliation would additionally cost 11,000 jobs within a year. Furthermore, imposing tariffs of either level would likely result in $25-30$ percent increases in module prices, thus dampening end demand for PV systems from an estimated $4.9 \mathrm{GW}$ in the absence of tariffs to 3.16 to $3.35 \mathrm{GW}$ (Berkman, Cameron, and Chang 2012). 
In addition to opposition from downstream installers, companies that sell solar manufacturing equipment and other upstream products such as polysilicon to China have also expressed strong concerns about the tariffs due to the potential negative impact that Chinese retaliation may exert on their exports to the Chinese market. For example, leading US suppliers of polysilicon and other key solar materials such as Dow Corning Corporation and Hemlock Semiconductor Group issued a statement highlighting the impact that a potential trade war over solar module production could have on both nations' economies and on the global viability of the solar industry. According to the statement, the United States exported $\$ 5.6$ billion in solar-related products in 2010 , including approximately $\$ 400$ million in net exports to China. The sharp drop in solar panel prices has not only generated significant benefits for consumers but has also encouraged the development of large-scale photovoltaic projects that benefit both the economy and the environment. Resolving the dispute through an adversarial confrontation would therefore impede the ability of both countries to capitalize on the lower prices made possible by healthy competition between global manufacturers. ${ }^{10}$ While far less vocal than the installers, opposition from these exporters further reinforced the arguments made by the installers, thus undercutting US ability to send a unified message to the Chinese.

Further complicating the story was China's growing investment in renewable energy in the United States. According to a World Resources Institute report, Chinese companies have made at least 124 investments in solar and wind industries in thirty-three countries between 2002 and 2011, especially in solar PV power plant and wind farm development. As the largest destination of these investments, the United States was the host of twenty-four solar projects and eight wind projects (Tan et al. 2013). Favorable macroeconomic conditions, the government's policy and financial support, and industry conditions have been considered as key factors that pushed Chinese companies to invest abroad. China's leading solar manufacturing companies, such as Suntech, Trina Solar, and Yingli Solar, are also its leading overseas investors. The growing presence of Chinese solar manufacturers in the US market thus lent to additional dissenting voices in the solar trade dispute.

For example, Solar Energy Industries Association (SEIA), which included US subsidiaries of Chinese solar manufacturers and US companies that sell raw materials and factory equipment to Chinese makers of solar panels, weighed in on the side of the installers and exporters. One SEIA member company, Suntech Power, which was owned by China's industry giant Suntech,voiced strong opposition to trade actions against 
China. As Suntech ships solar cells from China to the United States, where the cells are bolted together in Arizona for final delivery, the company made strong public statements that the trade restrictions would "not only put thousands of jobs at risk," but would also "inhibit solar technology's ability to compete against traditional forms of electricity generation" (Bradsher 2011). SEIA subsequently played a leading role in seeking a compromise solution to the solar trade dispute.

The substantial opposition to the trade action expressed by a wide range of actors in the United States thus reduced the need for Beijing to modify its practices. Indeed, following Beijing's decision to launch investigations into US clean-energy projects, the chief executives of four major Chinese solar power equipment producers reportedly stated at a news conference that they "had allies to fight Washington's allegations" as the Chinese industry is beneficial to the United States. The Chinese manufacturers suggested that not only are US companies major suppliers to the Chinese industry, US consumers also "benefit from the lower prices that result from the industry's concentration and competitiveness" (Areddy and Ma 2012). While the solar panel case took place outside the WTO framework, the above discussion suggests that the Chinese did not lose sight of the dissention within the US solar industry resulting from the linkages that China's inexpensive solar panel exports may have created with other parts of the US solar industry. Knowledge of such fissures within US politics derived from media reports and other news outlets thus reduced Beijing's willingness to align its policy with that preferred by the United States.

\section{Renewable Energy as a Strategic Emerging Industry in China}

Further reinforcing domestic divisions in the United States is the fact that as one of the strategic emerging industries with significant implications for the country's long-term economic growth, the renewable energy industry has received considerable support from the Chinese government. The central government in Beijing viewed industrial policy as a useful way both to sustain the viable development of the solar industry in the context of stiff international competition and to promote the country's transition to a low-carbon economy. ${ }^{11}$ The substantial investment that both the central and local governments have injected into solar development further raised the costs for Beijing to back out of its existing policy. In addition, the policy preferences of the central government on such a strategic issue are in fundamental alignment with those of the local governments and the industry, thus substantially reducing Beijing's willingness to make the desired policy concessions. 
The Role of the Central Government in Solar Industry Development

The Chinese government has played an indispensable role in shaping solar industry development. Chinese leaders saw renewable energy as a critical strategic opportunity not only because of the energy bottlenecks they faced at home but also because the United States is lagging behind in renewable energy development. Central government support was seen as crucial for China to close the relatively narrow gap in this sector, claim its spot as the next global technology leader, and realize the long-term goal of transitioning from a low-cost manufacturer to an economy led by higher-value-added technological innovation (USCC 2010; Hart 2011). The continued reduction in the cost of solar-generated electricity in comparison with the rising costs of fossil fuel, the greater sustainability and marginal environmental impact of solar energy, as well as solar energy's wide range of perceived benefits to the rest of the economy further enhanced the attractiveness of using industrial, trade, and technology policy to promote industry development.

In view of the strategic importance of the solar industry, the Chinese government has adopted several key policy instruments to promote solar industry development, including technology transfer requirements, local content demands, the provisions of readily available credit at low interest rates, tax incentives, low rates for land and raw materials, guaranteed price mechanisms for solar projects, and rebates on tax and interest (USCBC 2006).

The 2006 Renewable Energy Law (REL) and the Twelfth Five-Year Plan (FYP) set up the basic framework for renewable energy development in China. The REL established the State Council as the key agency responsible for managing renewable energy development, spelled out the key objective of in-country power generation, required grid enterprises to purchase renewable energy power generated within their grid and to provide grid connections, and provided the basic framework for tax incentives and financial subsidies (ECJRC 2011; Su, Hui, and Tsen 2010; Solangi et al. 2011). The Twelfth FYP unveiled in 2011 identified alternative energy as one of seven key "strategic emerging" industries and set the goal of expanding the share of nonfossil fuels in China's total energy consumption to 11.4 percent by 2015 and 15 percent by 2020 (USCC 2010).

China's 12th Five-Year Plan for the Solar Photovoltaic Industry (Solar 12th FYP), issued in February 2012, more specifically spelled out the goals of solar power industry development in the 2011-2015 period. In particular, the plan emphasized the need to promote industry develop- 
ment in order to "guarantee energy supply, establish a low-carbon society, promote economic restructuring, and foster strategic emerging industries." 12 To accomplish these objectives, the plan preserved considerable discretion for the Chinese government and allowed it to intervene extensively in the operations of individual solar companies through industrial plans and other policy directives. ${ }^{13}$ In addition, the Solar 12th FYP called for substantial government subsidies to support a strategic emerging industry such as solar, set out the goal of further internationalizing the solar industry as part of China's going abroad strategy, emphasized the need to promote and support national champions, and provided the Chinese government with considerable authority over various aspects of solar industry development. ${ }^{14}$

The Golden Sun program, unveiled in 2009 to spearhead the construction of solar farms, provides a good illustration of the generous subsidies provided by the government to the solar industry. Under the program, the Chinese government would pay for half of solar-farm developers' costs based not so much on how much electricity a solar farm produces but on how much a developer spends on a solar farm. In December 2012, the government announced a second phase of the program aimed at installing a total of $2.835 \mathrm{GW}$ of solar projects across the country (Feng 2012).

Overall, even though government support has resulted in considerable irrationalities, ${ }^{15}$ the wide range of public policies initiated by the Chinese government, including loans, direct subsidies, tax rebates, land grants, and support for research and development made possible by the 2006 REL and the Twelfth Five-Year Plan, have constituted a significant driving force behind rapid industry expansion.

\section{The Role of Local Government and Industry Associations}

Local governments have similarly been instrumental in fostering solar industry development. Strong backing by the central government, coupled with the solar industry's potentially important role in generating a high rate of return and hence in boosting the local economy, has led many local governments to follow suit by targeting the solar industry for support during the Twelfth FYP and offering tax breaks and subsidies in a competitive drive to attract investment and develop solar manufacturing parks. As a result of readily available credit, the city of Wuxi, home to the solar giant Suntech, has invested so heavily in solar farms that it quickly became a major center of solar manufacturing in China. Suntech, in particular, has undergone such rapid expansion in a short span of a few years that the company has not only gone public on the New York 
Stock Exchange in 2005 but has also surpassed Japan's Sharp Corp. to become the world's largest solar panel maker, spurring public offerings by other Chinese solar firms. The euphoria surrounding China's solar manufacturing boom in the early years of the industry's expansion generated a herd effect, prompting local officials and big banks to continue to inject easy credit into the industry, fueling further industry expansion (Ball 2013).

It should be noted that under the so-called Wuxi Model that has become popular across the country, local governments provided not only easy financing but also land and electricity at deeply discounted rates as well as assistance with hiring and infrastructure development. As the solar industry can both generate a high rate of gross domestic product (GDP) growth and be considered to be environmentally friendly, local government officials whose promotion prospect has increasingly come to hinge on their ability to promote rapid economic growth have identified the solar industry as a strategic industry of the future. At the peak of solar industry development, more than 300 cities across the country have proposed to make the solar industry a future pillar industry. Many of them have developed large-scale solar industrial parks or even solar cities with ambitious production goals. ${ }^{16}$ Overall, even though the symbiotic relationship between the government and industry has resulted in the capture of local government revenues by leading solar firms ${ }^{17}$ and the encouragement of highly polluting industrial activities, local government intervention to foster the conditions necessary for promoting the growth of an infant industry has become indispensable to early industry expansion.

Compared to the relatively dominant role of the central and local governments in promoting rapid industry growth, solar industry associations have been far less effective in championing the goals of industry development. There are several industry associations that are actively involved in advocating key industry objectives and coordinating the activities of member firms, including China New Energy Chamber of Commerce (CNECC), China Renewable Industry Association (CHNREIA), China Photovoltaic Society (CPVS), and the China Photovoltaic Industry Alliance (CPIA). In addition to these national-level industry associations, there also exist hundreds of industry associations at the subnational level. However, none of these associations has the power or authority to effectively influence and coordinate the activities of member firms. The fact that the solar industry is relatively fragmented, with the top ten companies accounting for only 50-60 percent of the market share, along with the financial difficulties experienced by the major firms 
in the events leading up to the solar trade disputes, has made it difficult for industry associations to be vocal advocates of industry interests (Jiang 2013).

The relative weakness of industry associations meant that instead of playing a proactive role in responding to the US AD and CVD investigations, solar industry associations have let the China Chamber of Commerce for Import and Export of Machinery and Electronics Products (CCCME) under the auspice of the Ministry of Commerce (MOFCOM) take the lead in coordinating the investigations (Jiang 2013). The relative fragmentation of solar industry associations has given rise to calls for consolidation and at the same time elevated the importance of the government in shaping China's response to the US trade challenge.

\section{Rapid Industry Expansion Leading to Overcapacity and Excessive Reliance on the Export Market}

In part because of government support and low entry barriers, ${ }^{18}$ fueled by the anticipation of future robust growth and rising global demand, China had overtaken the United States as the most attractive country for renewable energy investment by 2010 (Perkowski 2012). However, the rapid development of China's solar industry has also led to overcapacity and excessive reliance on the overseas export market as described previously. The skyrocketing global panel production resulting from the entry of Chinese firms not only caused a series of bankruptcies in the United States but also led prices to plunge in the global market. ${ }^{19}$ This in turn fed the bankruptcies of Chinese firms and contributed to the solar industry's considerable financial problems. From 2011 to 2012, the number of Chinese PV enterprises decreased by more than half, from 262 to 112 . By 2012 up to 90 percent of Chinese polysilicon makers had halted production and 80 percent of Chinese solar panel producers were either shut down or had to sharply reduce output. ${ }^{20}$ By 2012 China's ten largest solar panel companies had a cumulative debt of $\$ 27.7$ billion. Their average debt ratio, or the share of debt in total assets, reached an alarming level of 75.8 percent. Global overcapacity and the fierce price war even led Suntech to declare bankruptcy after defaulting on a $\$ 541$ million bond payment in 2013. ${ }^{21}$ Soon after Suntech's fall, the Bank of China reported that 21 percent of its solar loans were nonperforming or near default and that it had set aside only enough money to cover 11 percent of the bad loans. However, even as more than half of the PV enterprises have exited the market, China's PV generation capacity still reached $45 \mathrm{GW}$, or 700 percent of the 2009 level. ${ }^{22}$ 


\section{Chinese Government Response to the Solar Dispute}

When confronted with US trade challenges, the Chinese government has chosen to provide continued support to the industry in order to enhance its long-term sustainability rather than make the necessary policy adjustments to avoid even more costly trade restrictions in the future. Far from abandoning an industry exhibiting the paradoxes of government support, as Beijing's decision to allow one of the companies involved in this case to go bankrupt would seem to indicate, Beijing has adopted a number of measures in order to help the companies stay afloat.

Domestically, the Chinese government resorted to policies that would help to bolster the solar power market. For example, it set a major goal of expanding the solar energy market in order to boost domestic demand for solar-generated electricity. As a result of this initiative, the newly installed capacity of energy generated by solar panels in China surged from $0.45 \mathrm{GW}$ in 2010 to $4.5 \mathrm{GW}$ in 2011 . The government also set the target of creating a $10 \mathrm{GW}$ domestic market in 2012 (Michelsen 2012). In addition, efforts were undertaken to alleviate bureaucratic red tape to encourage growth. The State Grid announced a so-called Welcome, Support, and Service initiative that involved not issuing any charges for eligible distributed PV projects in order to reduce system costs.

At a State Council executive meeting in December 2012, the government identified excessive reliance on overseas markets and lack of sufficient domestic demand as key hurdles to future industry development and came up with five policies designed to further promote industry development, including accelerating the adjustment of industry structure and technological development; consolidating order in the industry; actively promoting the development of the domestic market for the application of solar and PV products; improving supporting policies and market mechanisms; and scaling back government intervention and prohibiting local protectionism. ${ }^{23}$

It is important to note that while the policies emphasized the need to encourage market mechanisms, they also preserved a key role for the government in shaping industry development. According to Shijiang Wang of the CPIA Secretariat, given the relatively high cost of solargenerated electricity, the PV industry is still an infant industry that needs considerable government support and promotion. The high production costs also need to be addressed through multiple mechanisms, including government subsidy, the long-term support of banking institutions and insurance companies, and the industry's internal development. CPIA Gen- 
eral Secretary Bohua Wang further suggests that the development of the PV industry depends on both "market expansion" and "cost reduction," a process that involves both the filtering out of uncompetitive enterprises on the basis of market competition and the creation of compensation mechanisms that defray the high cost of PV production and increase the affordability of PV products on the domestic market. ${ }^{24}$ In other words, in spite of recognition of the importance of reducing government intervention and fostering market forces, government support remained important in promoting the development of the domestic market.

Local government policies toward the solar industry similarly emphasize the importance of government regulation. In both Jiangsu and Jiangxi provinces, which are home to giant solar manufacturers, provincial governments adopted new policy guidelines that set far less ambitious revenue goals for the solar industry and set out to provide preferential support only to financially viable companies, accelerate mergers and acquisitions and the closure of uncompetitive firms, and encourage foreign direct investment by solar companies. Importantly, although these guidelines made numerous references to market forces, they allowed the government to retain considerable discretion in deciding which companies would continue to have access to credit or enjoy preferential interest rates. ${ }^{25}$

As the government sought to protect an industry with the potential of generating considerable revenue and given the extent of existing government involvement, it was perhaps not surprising that China made few policy adjustments in spite of repeated trade restrictions imposed by the United States. The dominant role of the National Development and Reform Commission (NDRC) in energy and environmental policymaking further enhanced the ability of the central government to influence policy direction in a way that is consistent with the country's long-term economic interests.

\section{Brief Comparisons of the Solar and Wind Power Cases}

I provide a detailed discussion of the domestic dynamics of the solar case without engaging in a full comparison of how this case compares to other TRIMs-related disputes such as wind power. This section offers a brief comparative analysis of US-China trade tensions in solar and wind power, suggesting that neither were US domestic interests as divided nor the resolve of the main Chinese players in defending the problematic practices as strong in the wind power as in the solar industry, at least during the period under consideration. While the Chinese government has also provided strong support to the wind industry for a relatively long period of time, the solar dispute took place at a time when the focus of 
Beijing's renewable energy policy was increasingly shifting from more established industries such as wind to newly emerging ones such as solar. While policymakers may be more attentive to an investment of $\$ 1$ billion than $\$ 200$ million, their calculation may be fundamentally altered if the $\$ 1$ billion was invested a decade ago in an industry that is increasingly established and mature and the $\$ 200$ million was invested more recently in an industry that is still trying to establish itself as a formidable global competitor. The more recent strategic shift in Beijing's renewable energy policy therefore substantially reduced incentives for policy reversal.

First, while there existed some divisions within the US wind power industry regarding the WTO case against China, such divisions were not nearly as significant as they were in the solar case. US wind power manufacturers were the major actors initiating the WTO filing against China. But unlike in the solar sector where there exist a significant number of both upstream and downstream businesses that rely on Chinese products, the number of US businesses that depend on Chinese supplies is far more limited because Chinese wind power manufacturers' exports to the United States trail far behind their domestic sales (Li and Wei 2012). Following the US tower dumping investigation, for example, officials of the China Wind Energy Association reportedly commented that the investigation will not have a big impact on the Chinese industry because most wind tower companies are focused on the Chinese market (Davidson 2012). Sinovel, a leading turbine manufacturer in China, commented that it had exported only four turbines to the United States. While already the second-largest turbine firm in the world by 2010 , the company's export figures are still small and expansion into the US market remains an important priority. Furthermore, even though growing Chinese exports and their cost-effectiveness are increasingly undercutting the competitive position of US suppliers, the US wind turbine market is still dominated by domestic companies such as GE (Lema, Berger, and Schmitz 2013; Glader 2010). Overall, Chinese manufacturers' expansion in foreign, including the US, markets has not been as impressive as in the solar industry. The continued dominance of US suppliers in the market means that there are relatively few businesses in the United States that depend on Chinese supplies as in the solar industry. As a result, US trade measures against China have not encountered as strong resistance in the wind power as in the solar industry. A close analysis of the US wind power industry's response to the proposed trade measures suggests that opposing voices to trade sanctions against China were almost nonexistent.

Second, in addition to suffering from the most serious domestic divide, the solar case is distinguished by intense leadership interest in pro- 
tecting the sector under consideration. While both the solar and wind power industries can be considered as "strategic emerging" industries, what made it especially difficult for the Chinese government to modify its practices in the solar case was the increasingly intense support the government provided to the solar industry in the period leading up to the trade disputes. To be sure, the Chinese government has similarly provided significant support for wind industry development. ${ }^{26}$ However, despite such strong support, more recent investment trends clearly demonstrate a shift away from more mature sectors such as wind in favor of nascent emerging industries such as solar. Under the Twelfth FiveYear Plan the government has provided considerable financial support to solar industry development. From 2009 and 2011, the government has invested nearly 10 billion RMB to support the development of solar projects such as the Golden Sun program and other model programs. It was estimated that state-owned banks had provided as much as $\$ 18$ billion in low-interest loans to solar cell manufacturers by $2012 .{ }^{27}$ In 2013 , government investment in the solar sector amounted to $\$ 120$ billion, or 44.6 percent of the country's total clean energy investment, compared to $\$ 90$ billion, or 33.4 percent of the total investment in the wind sector. In 2014, solar investment further increased to $\$ 150$ billion, or 48.3 percent of total clean energy investment. In comparison, the share of investment in wind has remained stagnant at 32.1 percent, or $\$ 100$ billion. While cumulative clean technology installed in the solar sector continues to lag behind that in the wind sector, reflecting the wind industry's mature status as a large-scale power generation source, the year-on-year percentage change in installed capacity was 193.8 percent for the solar sector, compared to just 19.7 percent for wind in 2013 (Koch-Weser and Meick 2015). These data thus clearly point to the growing emphasis of the government on establishing the nascent solar industry as a viable global competitor and one of the key strategic industries of the future.

There are several reasons for the government's growing support for the solar industry. First, the huge excessive production capacity in the solar industry leaves greater room for the government to regulate the market in order to absorb the excessive production and to ensure market order. Second, as China has greater control of the key production technology in the solar than in the wind industry, government support is seen to be capable of yielding greater benefits in an industry in which China has greater indigenous technological capacity. Along similar lines, the more rapid technological development in the solar sector means that government support can be more effective in reducing the cost of production and helping to achieve the goal of having 30 percent of its total energy 
requirements satisfied by renewable sources by 2050 . The potential to tap into the vast solar resources in western China, combined with considerations about the relative unpredictability of wind energy resulting from both seasonable fluctuations and regional variations further enhanced the attractiveness of investing in the solar industry. Fourth, even though the government under Premier Li Keqiang has tended to emphasize retreat from economic stimulus policies, it has at the same time shown a willingness to shield domestic industry from foreign protectionist pressures, especially in industries such as solar in which China has vital economic interests. ${ }^{28}$ As the central government investment priority increasingly shifted in favor of the solar industry, local governments rushed to provide credit and discounted land and electricity to the wind power industry on a scale that was not seen for the wind industry. ${ }^{29}$ The highly symbiotic relationship between the government and industry in the solar sector during the period under investigation therefore raised the costs of policy adjustments when Chinese practices were being challenged by the United States.

\section{Conclusion}

The above analysis underscores the importance of domestic politics for understanding why solar products have repeatedly emerged as a major point of contention in US trade relations with China. Despite the intense concerns the United States has expressed with Chinese practices, Washington's trade measures have nevertheless not been effective in generating long-term policy changes due to both divisions among domestic interest groups and Beijing's strong defense of a strategic emerging industry that is increasingly receiving stronger government support.

One potential alternative argument to the domestic politics explanation advanced above has to do with the different policy structure on the Chinese side. Specifically, it may be argued that in contrast to the wind turbine case, which involved a central government policy that could provide a more legitimate ground for WTO complaint and may also presumably be more easily addressed by the Chinese side to accommodate that complaint, the solar trade case involved multiple small, market-distorting policy measures with considerable variation at both the regional and sectoral levels. The relative fragmentation of the solar market thus made it more difficult for US solar companies to pursue their case through WTO litigation and reduced the incentive for US industry to launch WTO disputes in the first place. While plausible, the 
argument that going after a single instead of multiple targets is more likely to generate the desired result is difficult to sustain because it is reasonable to expect that a government will be more likely to fight fiercely over an issue that impinges significantly on either its national interests or the interests of key domestic constituencies. Indeed, many of the most difficult issues for WTO negotiation involve a single national policy targeted at a specific sector over which there exists intense domestic pressure on both sides. ${ }^{30}$ Furthermore, even with multiple policy levers as in the solar case, it is reasonable to expect that some of the issues are likely to command greater attention of US business interests and trade negotiators than others and therefore could more easily constitute the main target of trade disputes.

Several unique features of this case merit further discussion. First, greater attention to the strategic context of this case may be warranted. While the solar industry is not a "strategic trade" industry in the traditional sense, it has been considered by both US and Chinese leaders as crucial to the nation's long-term goals of increasing energy security, reducing carbon pollution, and promoting sustained economic growth. ${ }^{31}$ The strategic importance of the industry may therefore help us better understand both the intense pressure Washington applied on this issue and the difficulty it faced in getting Beijing to make the necessary policy adjustments.

Second, this case suggests that a potential impediment to effective US-China cooperation on global issues such as climate change may be rooted in domestic politics. While both countries have sought effective mechanisms to promote cooperation in clean energy development, pressure to maintain the competitive position of domestic industries may present a major hurdle to such efforts. This case additionally reveals that while Washington is committed to supporting the use of clean energy in developing countries, the realization of its stated policy goals may as well be constrained by both domestic politics and what would be considered viable tools to achieve these objectives.

A couple of policy implications follow the above discussion. First, the role of the Chinese government in fostering the development of the solar industry described in this article raises important questions about the relative role of the government versus that of the market in the development of a strategic industry in an emerging economy such as China. Beijing's support for the solar industry illustrates how government intervention in strategic industries, in particular intervention above and beyond what is necessary for the effective provision of the so-called social goods, may well generate market distortions leading to major trade fric- 
tions. How to effectively balance the roles of the government and the market to prevent market irrationalities from spilling over to China's foreign trade relations could therefore present a major challenge to the Chinese government.

In addition, the above analysis highlights the challenge China faces in balancing its internal and external demand. The solar industry has demonstrated a high degree of reliance on export markets and foreign technology during the course of its development, a pattern that is consistent with the export-oriented growth strategy that underlies China's phenomenal economic growth in the past three decades. However, as excessive reliance on overseas markets could generate heightened tensions in China's foreign trade relations, as the US-China trade disputes illustrate, it may be important for the Chinese government to cultivate its domestic market and to search for other policy tools, such as the development of overseas markets, in order to ensure the sustainable development of strategic emerging industries. Such a shift would also be consistent with China's attempt to reorient itself toward a model of economic development based on domestic consumption in the aftermath of the 2008 global financial crisis.

Second, the industry dynamics described here have substantial implications for understanding the trade disputes that flared up between China and the EU over PV products in 2013. Just as in the US-China solar disputes, global overcapacity resulting from the rapid expansion of the Chinese PV industry generated heightened tensions in EU-China trade relations. If the argument about the influence of domestic politics on US-China trade relations described in this article is valid, then we should expect the fragmentation of the solar industry in the EU, resulting from not only the global integration of solar manufacturing but also the divergent policy preferences among EU member states, ${ }^{32}$ along with the Chinese government's continued support for the solar industry, to preclude an easy compromise solution to the dispute. ${ }^{33}$

$\mathrm{Ka}$ Zeng is professor of political science and director of Asian Studies at the University of Arkansas. She was a visiting scholar at Renmin University of China in fall 2014. Her research focuses on China's role in the global economy, in particular Chinese trade policy, China-WTO issues, and China-related trade dispute dynamics. Dr. Zeng's books include Trade Threats, Trade Wars (2004) and Greening China (co-authored, 2011). 


\section{Notes}

I would like to thank the EAI Fellows Program on Peace, Governance, and Development in East Asia supported by the Japan Foundation, the Chiang Chingkuo Foundation for International Scholarly Exchange in Taiwan, and YBM/KIS, an education institute in South Korea, for their generous support for travel and research.

1. Author interview with officials of the China Photovoltaic Industry Alliance (CPIA), October 2014.

2. Remarks by Ambassador Froman at the Joint Commission on Commerce and Trade press conference, December 18, 2014.

3. World Trade Organization, "Understanding the WTO: Anti-Dumping, Subsidies, Safeguards: Contingencies, Etc." www.wto.org/english/thewto_e /whatis_e/tif_e/agrm8_e.htm\#top (accessed November 18, 2014).

4. World Trade Organization, "DS 419: China-Measures Concerning Wind Power Equipment," www.wto.org/english/tratop_e/dispu_e/cases_e/ds419 _e.htm (accessed April 12, 2013).

5. Prior to this case, the Chinese government in 2009 removed a controversial local content policy that would have required local governments planning wind power projects to source more than 70 percent from domestic sources.

6. Compared to WTO litigation, which not only involves lengthy adjudication and implementation periods but also requires considerable financial and human resources, domestic legal trade remedies such as AD/CVD investigations offer firms with strong concerns about foreign trade practices, especially practices that are not explicitly outlawed by the WTO, a much more streamlined process to seek import relief without impinging on diplomatic relations (Davis and Shirato 2007).

7. While domestic opposition did not prevent solar manufacturers from initiating the $\mathrm{AD} / \mathrm{CVD}$ investigations, it was able to influence the final duties, which were lower than what many industry executives and observers had expected ("U.S.-China Solar Trade Case Background"; Wesoff 2014).

8. "U.S. Commerce Department Announces Final Duties on Wind Tower Imports from China, Vietnam," 2012.

9. "U.S. Seeks Stiff Tariffs on Chinese Solar Panels," 2012.

10. "Striking Balance," 2011.

11. Author interview with Chinese renewable energy industry expert, June 14, 2014.

12. "12th Five-Year Plan for the Solar Photovoltaic Industry," 2011.

13. "Summary of China's 12th Five-Year Plans Relating to the Solar Industry," 2012.

14. Ibid. The amount of money to be invested in the seven strategic industries over the five-year period reportedly amounted to more than $\$ 1.5$ trillion (Lim and Rabinovitch 2010).

15. For example, some solar developers reportedly built solar farms, pocketed the subsidies, and then removed the solar panels and installed them elsewhere. The easy credit available under the Golden Sun program further led to considerable inefficiency (Ball 2013).

16. “Ge Difang Zhengfu Guangfu Zhengce Douyou Naxie Xinyi?” 2013. 
17. For example, LDK Solar based in the city of Xinyu in Jiangxi province has become a leading source of local revenue, contributing to about 95 percent of the taxes remitted by solar PV firms in the city in the first half of 2011.“Guangfu Chanye Kunqu, Difang Zhengfu Shi Zuikui Huoshou," 2012.

18. According to interviews with CPIA officials, the fact that the industry was dominated by nonstate enterprises meant that barriers to entry were relatively low. In addition, the heavy subsidies provided by the United States and the European Union to the solar industry between 2005 and 2007 resulted in high profit margins that allowed the industry to attract a relatively large number of new entrants. Author interview with senior CPIA official, June 28, 2013.

19. Between 2009 and 201 , as Chinese production of solar panels quadrupled, panel prices dropped by 40 percent, which in turn led to a sharp decline in Chinese exports. According to the CPIA, in 2012 orders for Chinese PV equipment dropped by 80 percent compared to the previous year (Ball 2013).

20. Tang Danlu, "Suntech's Fall Rings Alarm Bell for China's Solar Industry," Xinhuanet, March 25, 2013. http://news.xinhuanet.com/english/china/201303/25/c_132259438.htm.

21. Ibid.

22. "Zhongguo Guangfu Chanye, Haineng Yinglai Chuntian Ma?" 2013.

23. "PV Industry 'Five Major Policies' to Be Implemented," 2012.

24. "Zhongguo Guangfu Chanye, Haineng Yinglai Chuntian Ma?" 2013.

25. "Ge Difang Zhengfu Guangfu Zhengce Douyou Naxie Xinyi?" 2013.

26. For example, while China has agreed to eliminate prohibited subsidies upon its entry into the WTO, it has resorted to such measures in order to bolster the competitiveness of domestic wind power manufacturers and producers. These measures include the so-called Chengfeng Plan, which provides subsidies for loan interest and other preferential policies to wind power projects utilizing local instead of imported equipment, a specialized fund to compensate for the cost of production for domestic wind turbine producers using locally produced parts, R\&D subsidies, and the use of technology transfer requirements as a precondition for doing business in China. Indeed, government investment in the wind industry constituted 68 percent of the country's total clean energy investment, compared to 13 percent for the solar industry between 2005 and 2011 (Ma 2011; "Who's Winning the Clean Energy Race?" 2011).

27. "Zhongguo Xiang Taiyangneng Guangfu Chanye Paochu 'Jiushengquan," 2012.

28. Author interviews with anonymous Chinese officials involved in renewable energy policymaking, December 2014.

29. Author interviews with Chinese officials and academics, October 2014.

30. For example, cases involving agricultural subsidies remain some of the most intractable cases at the WTO due to strong protectionist pressure from powerful agricultural lobbies confronted by national governments.

31. See, for example, "Advancing American-Made Energy." www .whitehouse.gov/energy/securing-american-energy (accessed June 25, 2014).

32. For example, Germany and Britain have expressed concerns that the EUChina trade spat over solar PV could jeopardize ties with the EU's second-largest trading partner (“EU, China Near Deal to Defuse Solar PV Spat,” 2013). 
33. For discussions of EU industries' ongoing concerns with China's solar policies in spite of the settlement agreement reached in July 2013, see, for example, Neidlein and Meza (2013).

\section{References}

“Advancing American-Made Energy."www.whitehouse.gov/energy/securingamerican-energy (accessed June 25, 2014).

Areddy, James, and Wayne Ma. 2012."Beijing Flares Up at U.S. on Solar Tariff." Wall Street Journal, May 25, 1.

Ball, Jeffrey. 2013. "The Changing Face of the Chinese Solar Industry." June 20. www.earthtechling.com/2013/06/the-changing-face-of-the-chinesesolar-industry (accessed June 27, 2013).

Berkman, Mark, Lisa Cameron, and Judy Chang. 2012. "The Employment Impacts of Proposed Tariffs on Chinese Manufactured Photovoltaic Cells and Modules." Brattle Group Research Report Prepared for the Coalition for Affordable Solar Energy, January 30. http://coalition4affordablesolar.org /wp-content/uploads/2012/01/TBG_Solar-Trade-Impact-Report.pdf (accessed September 23, 2013).

Blanchard, Jean-Marc F. 2013. "The Dynamics of China's Accession to the WTO: Counting Sense, Coalitions and Constructs." Asian Journal of Social Science 41: 263-286.

Blanchard, Jean-Marc F., and Norin M. Ripsman. 2008. "A Political Theory of Economic Statecraft.” Foreign Policy Analysis 24, 4: 371-398.

Bradsher, Keith. 2011."U.S. Solar Panel Makers Say China Violated Trade Rules." New York Times, October 19.

Bradsher, Keith, and Diane Cardwell. 2012. "U.S. Slaps High Tariffs on Chinese Solar Panels.” New York Times, May 17.

Cardwell, Diane. 2014. "U.S. Imposes Steep Tariffs on Chinese Solar Panels." New York Times, December 16.

Carus, Felicity. 2012. "Solar Tariff Ruling on Chinese PV Imports Divides U.S. Industry." AOL Energy, March21.

Chen, Liqiang, and Xinquan Tu. 2013."Meiguo Duihua Xinnengyuan Chanye Shishi Shuangguanzhi Fanbutie' Zhanlue Yanjiu” [Strategic studies of U.S. 'dual-track anti-subsidy' policy against China's renewable energy industry]. Journal of International Trade 5: 67-77.

Davidson, Ros. 2012. "Tower 'Dumping' Probe Marks New Chapter in Trade War." Wind Power Monthly, January 26.

Davis, Christina L., and Yuki Shirato. 2007. "Firms, Governments, and WTO Adjudication: Japan's Selection of WTO Disputes.” World Politics 59, 2: 274-313.

"EU, China Near Deal to Defuse Solar PV Spat." 2013. Sydney Morning Herald, July 25.

European Commission Joint Research Center (ECJRC). 2011. "PV Status Report 2011 - Research, Solar Cell Production and Market Implementation of Photovoltaics.” JRC Scientific and Technical Reports, EUR 24807, July. 
Evans, Peter B., Harold K. Jacobson, and Robert D. Putnam, eds. 1993. DoubleEdged Sword: International Bargaining and Domestic Politics. Berkeley: University of California Press.

Feng, Becky Beetz/Wenjing. 2012. "China: $2.83 \mathrm{GW}$ of Solar to Be Installed Under Golden Sun Program.” PV Magazine, December 11.

"Ge Difang Zhengfu Guangfu Zhengce Douyou Naxie Xinyi?" [What are the new elements in local government solar PV industry?]. 2013. September 13. www.topenergy.org/news_87433.html (accessed June 24, 2014).

Glader, Paul. 2010. "GE Leads U.S. Market for Wind Turbines." Wall Street Journal, April 16.

“Guangfu Chanye Kunqu, Difang Zhengfu Shi Zuikui Huoshou” [Local governments are to blame for the dilemma of the solar PV industry]. 2012. August 6. http://guangfu.bjx.com.cn/news/20120806/378237-2.shtml (accessed June 24, 2014).

Harsanyi, John C. 1969. "Rational-Choice Models of Political Behavior vs. Functionalist and Conformist Theories." World Politics 21, 4: 513-538.

Hart, Melanie. 2011. "China Eyes Competitive Edge in Renewable Energy." Center for American Progress Report, August 24.

- - . 2012. "What Does the Solar Trade Dispute Mean? Shining a Light on U.S.-China Clean Energy Cooperation," February 9. http://thinkprogress.org/climate/2012/02/09/422282/solar-trade-us-chinaclean-energy-cooperation (accessed April 15, 2013).

Hart, Melanie, and Kate Gordon. 2012. "The Complexities of the U.S. Decision on Chinese Solar Panel Imports: We Need to Think Long Term About U.S.China Clean Energy Trade." March 15. www.americanprogress.org /issues/green/news/2012/03/15/11330/the-complexities-of-the-u-s-decisionon-chinese-solar-panel-imports (accessed September 23, 2012).

Hasenclever, Andreas, Peter Mayer, and Volker Rittberger. 2000. "Integrating Theories of International Regimes." Review of International Studies 26, 1: 3-33.

Hong Jie and Shi Huang. 2014. "The Fundamental Reasons for the U.S. DoubleRemedies Against China in the Solar Industry" [Meiguo Duiyua Guangfu Chanye Shishi 'Shuangfan' Cuoshi de Shenceng Yuanyin]. International Economic Cooperation [Guojijingjihezuo] 1:46-52.

Hudson, M. Valerie, and Christopher S. Vore. 1995. "Foreign Policy Analysis Yesterday, Today, and Tomorrow." Mershon International Studies Review 39, 2: 209-238.

Jiang, Zhuoying. 2013. "Guangfu Hangye Xiehui Hunzhan" [The chaotic state of solar PV industry associations]. May 7. www.21 cbh.com/HTML/20135-7/1MNDE3XzY3ODA1Mw.html (accessed June 24, 2014).

Keohane, Robert O. 1988."International Institutions: Two Approaches.” International Studies Quarterly 32, 4: 379-396.

Koch-Weser, Iacob, and Ethan Meick. 2015."China's Wind and Solar Sectors: Trends in Deployment, Manufacturing, and Energy Policy." U.S.China Economic and Security Review Commission Staff Research Report, March 9. 
Lema, Rasmus, Axel Berger, and Hubert Schmitz. 2013. "China's Impact on the Global Wind Power Industry." Journal of Current Chinese Affairs 42, $1: 37-69$.

Li, Dong, and Xiaosha Wei. 2012. "Zhongmei Qingjie Nengyuan Maoyi Moca Dongxiang, Yuanyin, Ji Duice Yanjiu" [Trend, causes, and policy analysis of U.S.-China clean energy trade frictions]. Qiu Suo 11: 26-31.

Lim, Benjamin Kang, and Simon Rabinovitch. 2010. "China Mulls \$1.5 Trillion Strategic Industries Boost." Reuters, December 3. www .reuters.com/article/2010/12/03/us-china-economy-investment-idUSTRE6B 16U920101203 (accessed October 2, 2013).

Louche, Celine, Angus Lambkin, and Padraig Oliver. 2007. "Study on the Future Opportunities and Challenges of EU-China Trade and Investment Relations-Study 11: Sustainable Technologies and Services." www.development-solutions.eu/media/docs/Study\%2011 $\% 20$ of\%2012\%20Sustainable\%20Technologies\%20\&\%20Services.pdf (accessed April 19, 2013).

Lu, Yao. 2012. "No Winners in the Solar Trade War Between China, the U.S. and E.U." China Briefing, December 20.

Ma, Wenjing. 2011. "Research on U.S. 301 Investigation of China's Green Technology Policies." Master's thesis, Northeastern University of Finance and Economics.

Martin, Lisa L., and Beth A. Simmons. 1998. "Theories and Empirical Studies of International Institutions." International Organization 52, 4: 729-757.

Michelsen, Charis. 2012. "China's New Distributed Solar PV Policies to Boost Distributed Solar to 35\% Market Share, Report Finds." December 4. http://cleantechnica.com/2012/12/04/chinas-new-distributed-solar-pv -policies-to-boost-distributed-solar-to-35-market-share-report-finds /\#H7pCKY45ODO8fLAv.99 (accessed July 24, 2013).

Mufson, Steven. 2012. “China Asks WTO to Block U.S. Tariffs.” Washington Post, May 25.

Neidlein, Hans-Christoph, and Edgar Meza. 2013. "E.U.-China Deal Continues to Irk Industry." PV Magazine, August 20.

Odell, John S. 1993. "International Threats and Internal Politics: Brazil, the European Community, and the United States, 1985-1987." In Double-Edged Sword: International Bargaining and Domestic Politics, ed. Peter B. Evans, Harold K. Jacobson, and Robert D. Putnam, 233-264. Berkeley: University of California Press.

O'Tooley, James. 2012. "U.S. Slams Chinese Solar Panels with New Tariffs." CNNMoney, May 17.

Parker, James. 2012. “Lights Out for China's Solar Power Industry?" The Diplomat, December 8. http://thediplomat.com/pacific-money/2012/12/08/lightsout-for-chinas-solar-power-industry (accessed September 28, 2013).

Perkowski, Jack. 2012."China Leads the World in Renewable Energy Investment.” Forbes, July 27.

Politi, J., and J. Lerner. 2012. "U.S. Sets Tariffs for Chinese Solar Cells.” Financial Times, March 20. 
“PV Industry 'Five Major Policies' to Be Implemented.” December 20, 2012. http://guangfu.bjx.com.cn/news/20121220/409017.shtml (accessed July 31, 2013).

Remarks by Ambassador Froman at the Joint Commission on Commerce and Trade Press Conference: Concrete Results That Support U.S. Jobs and Economic Growth, December 18, 2014. https://ustr.gov/about-us/policyoffices/press-office/speechestranscripts/2014/december/remarksambassador-froman (accessed May 28, 2015).

Shih, Victor. 2004. "Dealing with Non-Performing Loans: Political Constraints and Financial Policies in China." China Quarterly 180: 922-944.

Solangi, K. H., M. R. Islam, R. Saidur, N. A. Rahim, and H. Fayaz. 2011. “A Review on Global Solar Energy Policy." Renewable and Sustainable Energy Reviews 15, 4: 2149-2163.

"Striking Balance: How the Solar Industry Benefits from the U.S. and China." 2011. Statement by Robert D. Hansen, president and CEO, Dow Corning Corporation; Stephanie A. Burns, chairman, Dow Corning Corporation; and Andy Tometich, president, Hemlock Semiconductor Group. December 15. www.dowcorning.com/content/news/striking_balance.aspx (accessed September 24, 2013).

Su, Jack, Simone S. Hui, and Kevin H. Tsen. 2010. "China Rationalizes Its Renewable Energy Policy.” Electricity Journal 23, 3: 26-34.

"Summary of China's 12th Five-Year Plans Relating to the Solar Industry." 2012. Prepared by the international trade practice of Wiley Rein, LLP, based in Washington, DC, for the Coalition for American Solar Manufacturing. www.americansolarmanufacturing.org/news-releases/chinas-five-year-planfor-solar-analysis.pdf (accessed October 3, 2013).

Tan, Xiaomei, Yingzhen Zhao, Clifford Polycarp, and Jianwen Bai. 2013. "China's Overseas Investments in the Wind and Solar Industries: Trends and Drivers." World Resources Institute Working Paper.

"12th Five-Year Plan for the Solar Photovoltaic Industry." 2011. www .americansolarmanufacturing.org/news-releases/chinas-five-year-plan-forsolar-translation.pdf (accessed October 2, 2013).

United States-China Business Council (USCBC). 2006. "China's Implementation of Its World Trade Organization Commitments." Written testimony prepared for the Office of the USTR, September 23. www.uschina.org (accessed April 15, 2013).

United States Trade Representative (USTR). 2011. "China Ends Wind Power Equipment Subsidies Challenged by the United States in WTO Dispute." www.ustr.gov/about-us/press-office/press-releases/2011/june/china-endswind-power-equipment-subsidies-challenged (accessed April 12, 2013).

U.S.-China Economic and Security Review Commission (USCC). 2010. "2010 Report to Congress." www.uscc.gov (accessed April 18, 2013).

"U.S.-China Solar Trade Case Background." www.chinaglobaltrade.com/article/us-china-solar-trade-case-background (accessed December 2, 2014).

"U.S. Commerce Department Announces Final Duties on Wind Tower Imports from China, Vietnam.” 2012. ICTSD Bridges, December 19. 
“U.S. Seeks Stiff Tariffs on Chinese Solar Panels." 2012. USA Today, October 11 .

Wang, Fei-Ling. 2005. "Preservation, Prosperity, and Power: What Motivates China's Foreign Policy." Journal of Contemporary China 14, 45: 669-694.

Wang, Shijiang. 2011. "Guangfu Chanye de Jinyou" [The short-term worries of the PV industry]. Zhongguo Jingji he Xinxihua [Chinese economy and informatics], June 23.

Wesoff, Eric. 2014. "Solar World Wins Again: U.S.-China Solar Trade War Deepens." Greentech Media, July 29.

"Who's Winning the Clean Energy Race?" 2011. Pew Charitable Trusts Report.

"Zhongguo Guangfu Chanye, Haineng Yinglai Chuntian Ma?" [Can the Chinese PV industry usher in another spring?]. 2013. April 6. http://biz.xinmin.cn /2013/04/06/19580654_2.html (accessed October 16, 2013).

"Zhongguo Xiang Taiyangneng Guangfu Chanye Paochu 'Jiushengquan"” [China throws lifebuoy at the solar PV industry]. 2012. October 9. http://guangfu.bjx.com.cn/news/20121009/392859.shtml (accessed November 18, 2014). 